ENTREPRENEURSHIP AND SUSTAINABILITY ISSUES

ISSN 2345-0282 (online) http://jssidoi.org/jesi/

2020 Volume 8 Number 2 (December)

http://doi.org/10.9770/jesi.2020.8.2(6)

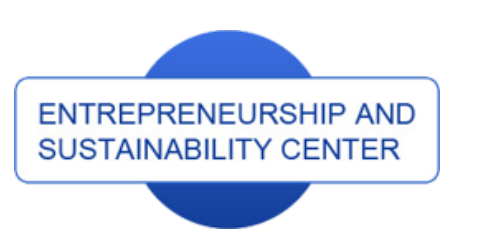

Publisher

$\underline{\text { http://jssidoi.org/esc/home }}$
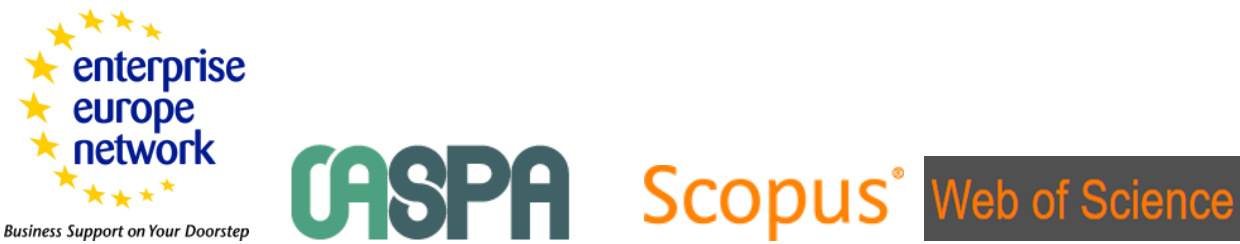

Business Support on Your Doorstep

1) Clarivate

Analytics

\title{
MARKET FOR MEMRISTORS AND DATA MINING MEMORY STRUCTURES FOR PROMISING SMART SYSTEMS *
}

\author{
Andrey I. Vlasov ${ }^{1}$, Ivan V. Gudoshnikov ${ }^{2}$, Vladimir P. Zhalnin ${ }^{3}$, Aksultan T. Kadyr ${ }^{4}$, \\ Vadim A. Shakhnov ${ }^{5}$ \\ 1,2,3,4.5 Bauman Moscow State Technical University, 5 Vtoraya Baumanskaj Str., Moscow, 105005, Russian Federation
}

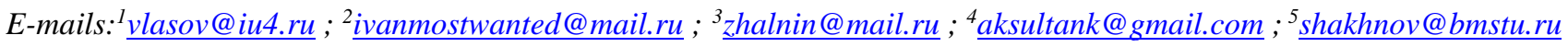

Received 18 March 2020; accepted 15 July 2020; published 30 December 2020

\begin{abstract}
The article examines the market for promising memristor-based memories for smart systems. The implementation of smart systems is characterized by the widespread use cyber-physical systems, predictive maintenance, AR/VR (Augmented/Virtual Reality) technologies, the Internet of Things (IoT), and Machine Learning algorithms. To stimulate their development, an increasing amount of computational resources and new data storage technologies is required. The current study aims to analyze the development of today's memristive technologies market in the context of their influence on the development of smart systems. The authors discuss the key stages of the market's formation and assess the possible effect of memristive technology on various spheres of society's life. The research results show that the application of memristive technology can affect the development dynamics of both data mining and promising data storage systems. The estimates obtained demonstrate that the memristor market is highly competitive and there are a considerable number of active participants operating on it. The majority of companies expand their market presence by entering various end-user segments. The annual market growth rate will average about $80 \%$ and reach an estimate of USD 8.9 billion by 2024 and USD 13.5 billion by 2027 .
\end{abstract}

Keywords: memristor market; industry digitalization; data storage; data mining; smart systems

Reference to this paper should be made as follows: Vlasov, A.I., Gudoshnikov, I.V., Zhalnin, V.P., Kadyr, A.T., Shakhnov, V.A. 2020. Market for memristors and data mining memory structures for promising smart systems. Entrepreneurship and Sustainability Issues, 8(2), 98-115. http://doi.org/10.9770/jesi.2020.8.2(6)

JEL Classifications: D40, O14, O32, M15

\footnotetext{
* Some results of the project were obtained with the financial support of the Ministry of Science and Higher Education for the project No. 0705-2020-0041 "Fundamental research of methods of digital transformation of the component base of microand nanosystems".
} 


\section{ENTREPRENEURSHIP AND SUSTAINABILITY ISSUES}

ISSN 2345-0282 (online) http://jssidoi.org/jesi/ 2020 Volume 8 Number 2 (December) http://doi.org/10.9770/jesi.2020.8.2(6)

\section{Introduction}

The rapid development of digital technology and the widespread adoption of smart systems have emphasized the key role of Big Data management. There are a number of major trends in the digital transformation of industry that are worth mentioning: autonomous robots (Yudin et al., 2017); cloud computing and storage (Che, Safran \& Peng, 2013); CAD systems (modeling and simulation) (Demin \&Vlasov, 2017); the Internet of Things (Berdyugina, Krivoshein \& Vlasov, 2018); and augmented reality (Che, Safran \& Peng, 2013). These technologies, when introduced in manufacturing, will lead to the creation of smart factories and initiate a new era in all sectors of industry, which can result in the fourth industrial revolution (The fourth..., 2017), or Industry 4.0 (Witten \& Frank, 2016). For this to happen, vast computational resources and storage space are needed.

Computational resources and data storage technology are approaching their maximum capability year after year. Non-volatile CMOS-based memory has already reached its full potential. However, data volumes keep growing, so there is a need to discover a brand-new principle of data storage (Vasilyev \& Chernov, 2012). Solutions in this field are characterized by the application of cyber-physical systems (Lee, 2006; Lee \& Seshia, 2011), predictive maintenance (Grigoriev et al., 2018), AR/VR (Augmented/Virtual Reality) technologies (Che, Safran \& Peng, 2013), the Internet of Things (IoT) (Lee, 2006; Lee \& Seshia, 2011), Machine Learning algorithms (Whitaker et al., 2018), and decentralized architecture (Blockchain technology) of Big Data analysis and processing (Che, Safran \& Peng, 2013; Muraviev et al., 2019). However, among other solutions, this is a memristor that is considered a promising device in numerous analog and digital applications, especially in memory chips, logic circuits, and neural networks.

The purpose of the paper is to analyze the development of the market for the modern component base of smart systems based on memristor technology that ensure the implementation of intelligent data processing algorithms and methods for their storage.

\section{Literature review}

Digital transformation involves manipulating not only technical, but also economic, social and other data that are necessary to manage digital production processes in a more effective manner (Litau, 2018a,b). A continuous increase in information volumes has led to the creation of a separate class of data, namely Big Data (Che, Safran \& Peng, 2013; Muraviev et al., 2019). To process large volumes, network computing technology has to be used (Veretennikov, 2017), whereas the creation of the memristor component base is believed to be a promising solution in the field of data storage.

A memristor is a non-linear two-terminal electrical component relating electric charge and magnetic flux linkage (Jeong \& Shi, 2019). There are various methods for fabricating memristors. The most popular of them are lithography (Jung, 2004), atomic layer deposition (Emelyanov et al., 2015), pulsed laser deposition (Puurunen, 2005) and sputter deposition (Wasa \& Hayakawa, 1993). The technological evolution of the memristor-related component base is presented in Fig. 1. The research studies devoted to memristors are gaining in popularity. The number of international scholarly publications increased from 2 pieces in 2005 to 48 pieces in 2015. The number of international patent applications is also rising - from 40 in 2005 to 158 in 2015 (Borodina et al., 2017). 


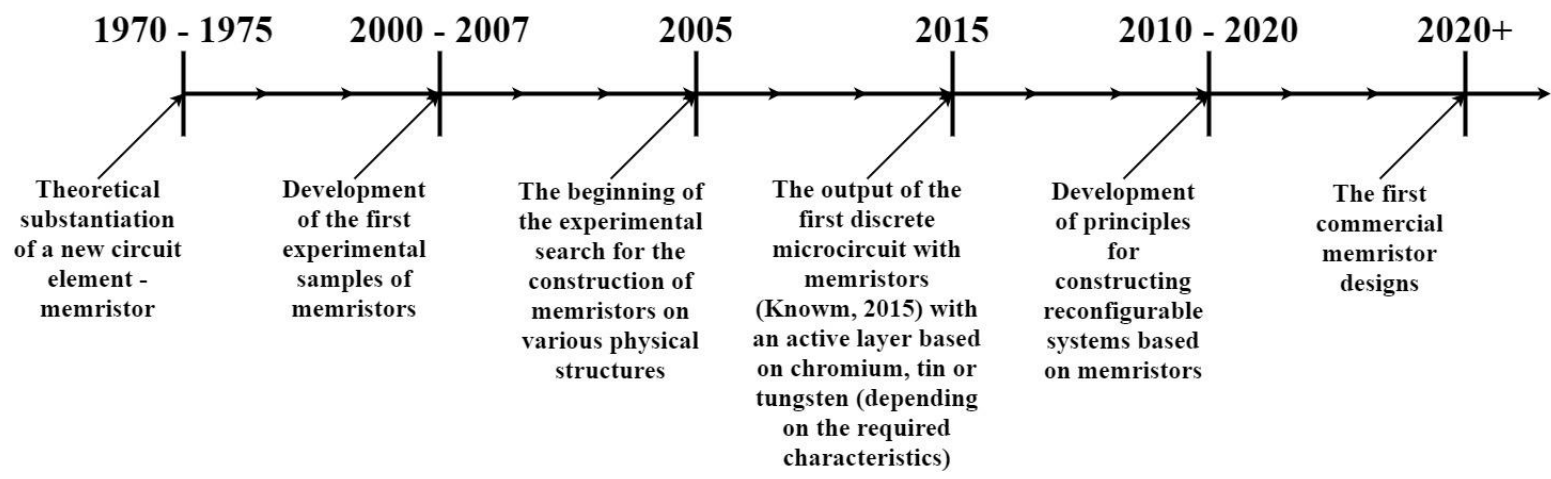

Fig. 1. Memristor Development Time line

When analyzing the development trends in memristor technologies, it is worth noting their high versatility (Ho, Huang \& Li, 2009). In terms of memory chips, memristors can be applied in cell structures of resistive randomaccess memory (RRAM) and in memristor-based content addressable memories (MCAM) using a combination of memristor and memory cell technology, as well as in multilevel memristor memory (MLMM) (Yener \& Kuntman, 2012). Due to the powerful capabilities of memristor technology, Ho and Huang (2009) suggested using these advantages for making calculations directly inside the system, eliminating the need to upload data to the cloud and thus increasing the security of such systems. Memristor-based logic has a remarkable ability that allows arranging memory cells on a single chip. Memristors can be applied in the development of switching units in field-programmable gate array (FPGA) (Sampath, Mane \& Ramesha, 2015).

There are three main directions for the research of memristors: developing various types of memristors, searching for memristor manufacturing options, and dealing with the problem of manufacturing memristors (Sherief et al., 2019) (Fig. 2).

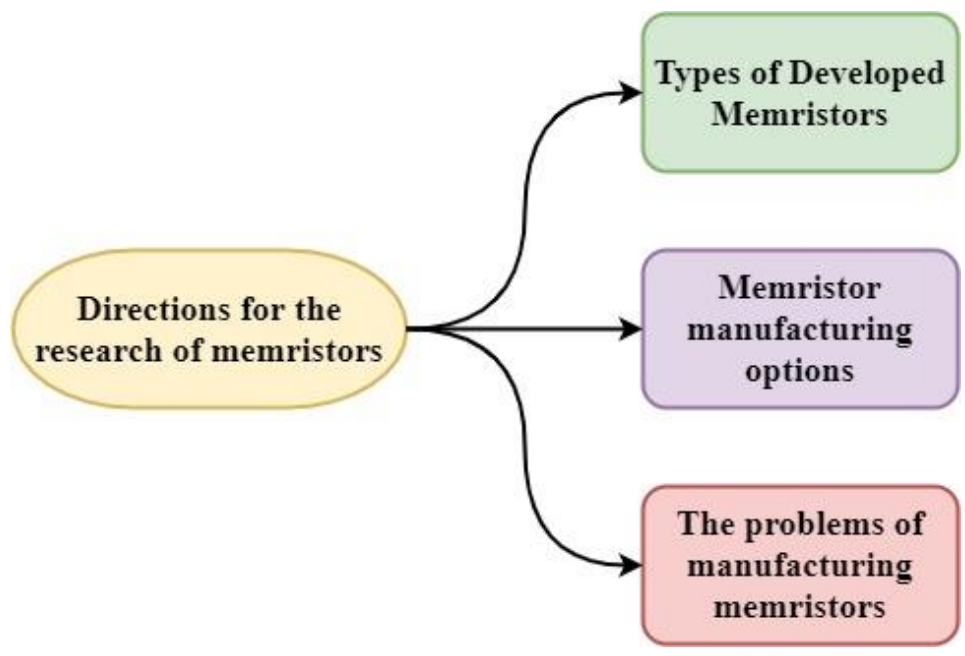

Fig. 2. Directions for the research of memristors

Currently, the memristor market's investment attractiveness is at its early stage of development as there is lack of devices ready for mass production (TMR, 2017). The formation of the memristive technology market is affected by a basic operational contradiction (Fig. 3): if a material of better quality and of higher price is used to fabricate memristors, the quality of the memory created is enhanced in terms of the number of writes and response time; 
however, it causes a serious rise in production costs and makes it difficult to start mass production. The choice of a memristor material determines the "memory strength" reflected in the number of rewrite cycles and the total cost of production.

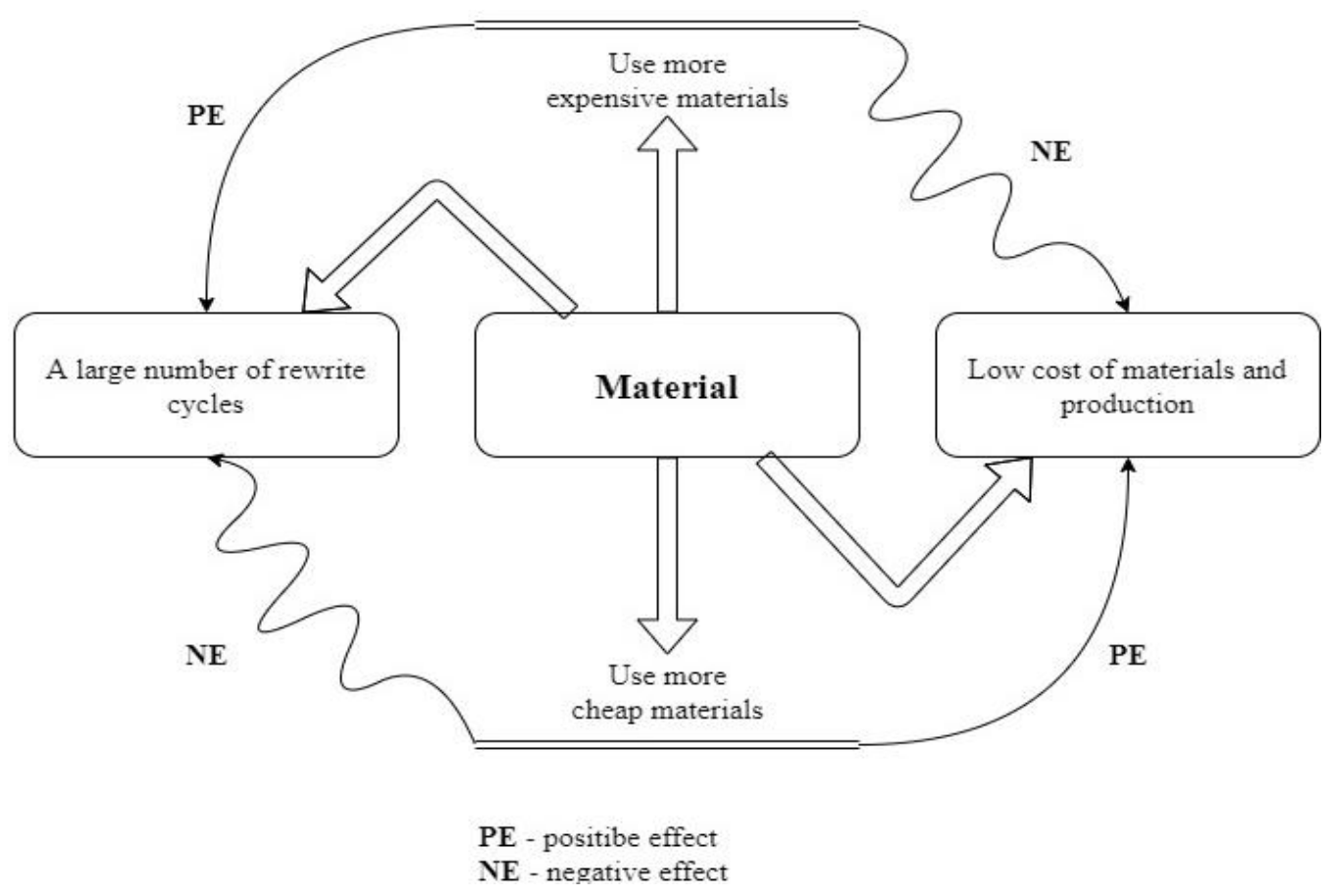

Fig. 3. Operational controversy scheme

Memory devices are increasingly becoming a bottleneck in data storage and data retrieval processes, and this limits storage performance. To improve computing speed significantly, scientists are striving to design smaller and denser memory devices that operate at high speed and consume low power (RM, 2018). With the advent of advanced technologies, data storage systems process more information than ever before. To do so, they should be of high performance, accessible, scalable, and manageable (Shukla \& Sharma, 2017). The main studied parameters of memristor technologies and their influence are shown in Table 1.

Table 1. Effect of memristive technologies parameters on their properties

\begin{tabular}{|l|l|}
\hline \multicolumn{1}{|c|}{ Parameter } & \multicolumn{1}{c|}{ Effect } \\
\hline Storage density & Capacity increase (Vasilyev \& Chernov, 2012) \\
\hline Response time & Increased data processing speed (Matkarimov, 2018) \\
\hline Synaptic properties & Empowering Artificial Intelligence (Snider et al., 2011) \\
\hline Power efficiency & Computing systems autonomy (Ho, Huang \& Li, 2009), power capacity (MM, 2017) \\
\hline
\end{tabular}

The forecast properties of memristors and the current memories are compared in Table 2 (Sherief et al., 2019; TMR, 2017; RM, 2018; Shukla \& Sharma, 2017). 
Table 2. Memory-related memristor properties

\begin{tabular}{|l|l|l|l|l|l|l|}
\hline \multicolumn{1}{|c|}{ Property } & \multicolumn{1}{c|}{ Memristor } & \multicolumn{1}{c|}{ PCM } & \multicolumn{1}{c|}{ STTRAM } & \multicolumn{1}{c|}{ DRAM } & \multicolumn{1}{c|}{ Flash } & \multicolumn{1}{c|}{ HDD } \\
\hline Storage density $\left(\mathrm{F}^{2}\right)$ & \multicolumn{1}{c}{4} & $8-16$ & $37-64$ & $6-8$ & $4-6$ & $2 / 3$ \\
\hline Energy per bit $(\mathrm{pJ})$ & $0.1-3.0$ & $2-27$ & 0.1 & 2 & 10000 & $1-10 \times 10^{9}$ \\
\hline Read timing $(\mathrm{ns})$ & $10-100$ & $20-70$ & $10-30$ & $10-50$ & 25000 & $5-8 \times 10^{6}$ \\
\hline Write timing $(\mathrm{ns})$ & 10 & $50-500$ & $13-95$ & $10-50$ & 200000 & $5-8 \times 10^{6}$ \\
\hline Retention & Years & Years & Weeks & $<<$ Seconds & Years & Years \\
\hline Rewrite cycle & $10^{12}$ & $10^{7}$ & $10^{15}$ & $10^{15}$ & $10^{6}$ & $10^{4}$ \\
\hline
\end{tabular}

Based on recent studies, it can be concluded that the use of memristor technology will affect the dynamics of the development of both data mining and promising data storage systems (Vasilyev \& Chernov, 2012; Vera-Tasama, Gomez-Cano \& Marin-Hurtado, 2019; Marani, Gelao \& Perri, 2015).

\section{Methods}

Designing an approach to the problem of analyzing the dynamics of the memristor market development includes the formulation of the theoretical framework of the research, analytical models, search queries, hypotheses, as well as the identification of the factors that can affect the nature of the study.

Analytical research methods are diverse (Fig. 4). 
ENTREPRENEURSHIP AND SUSTAINABILITY ISSUES

ISSN 2345-0282 (online) http://jssidoi.org/jesi/ 2020 Volume 8 Number 2 (December) http://doi.org/10.9770/jesi.2020.8.2(6)

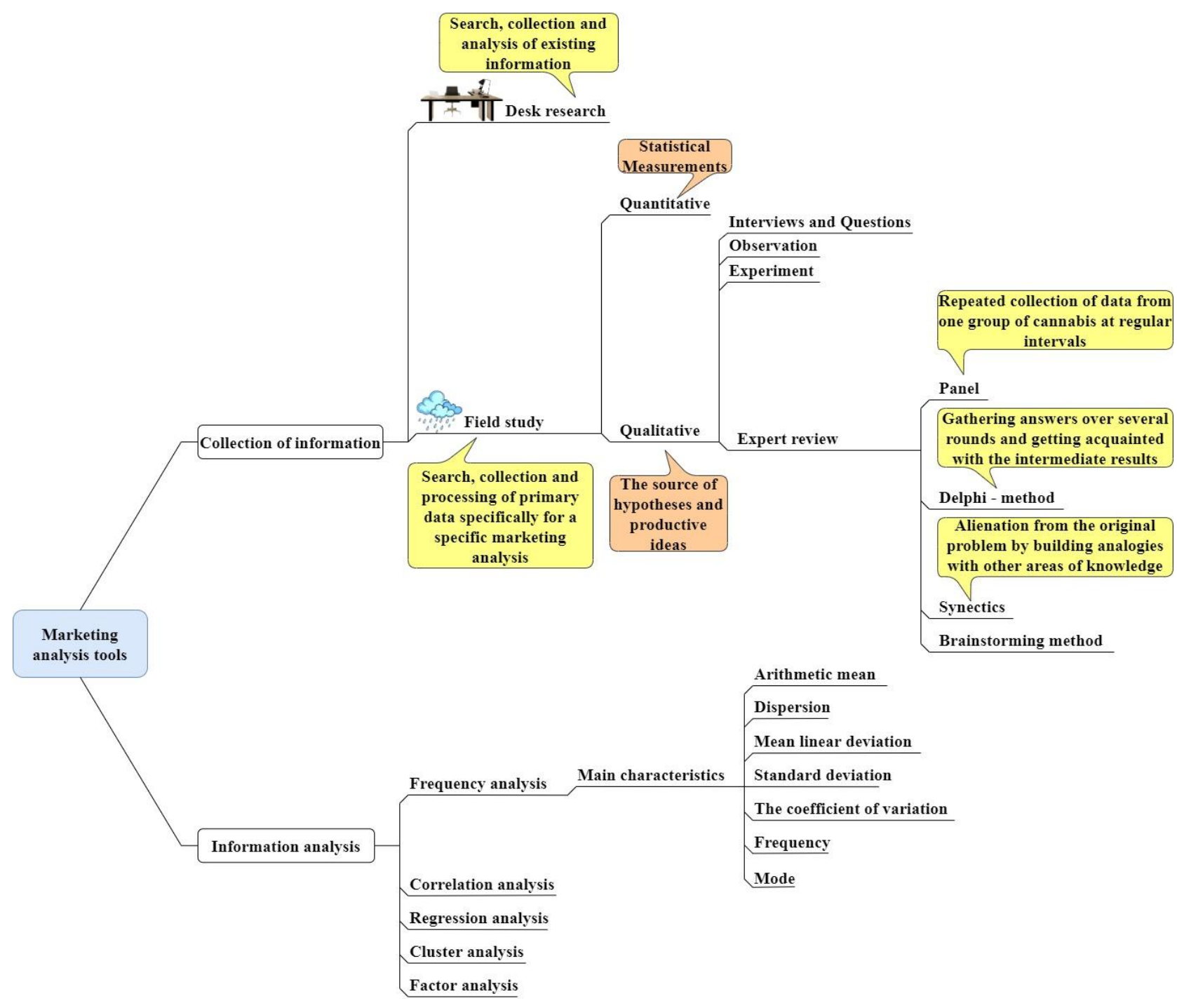

Fig. 4. System analysis methods

The expert approach, upon which the current study is built, should be discussed in more detail. Methods of expert assessments are methods of organizing work with experts and processing opinions of experts expressed in a quantitative and (or) qualitative form.

The research procedure suggests direct communication of expert opinions.

When analyzing expert assessments, a variety of statistical methods can be utilized (Table 3): consistency check (or expert classification, if no consistency is observed) and averaging expert opinions within an agreed group. It is a widespread approach to use simultaneously the mean ranks method and the median ranks method. 
Table 3. Methods and algorithms for analyzing expert assessments

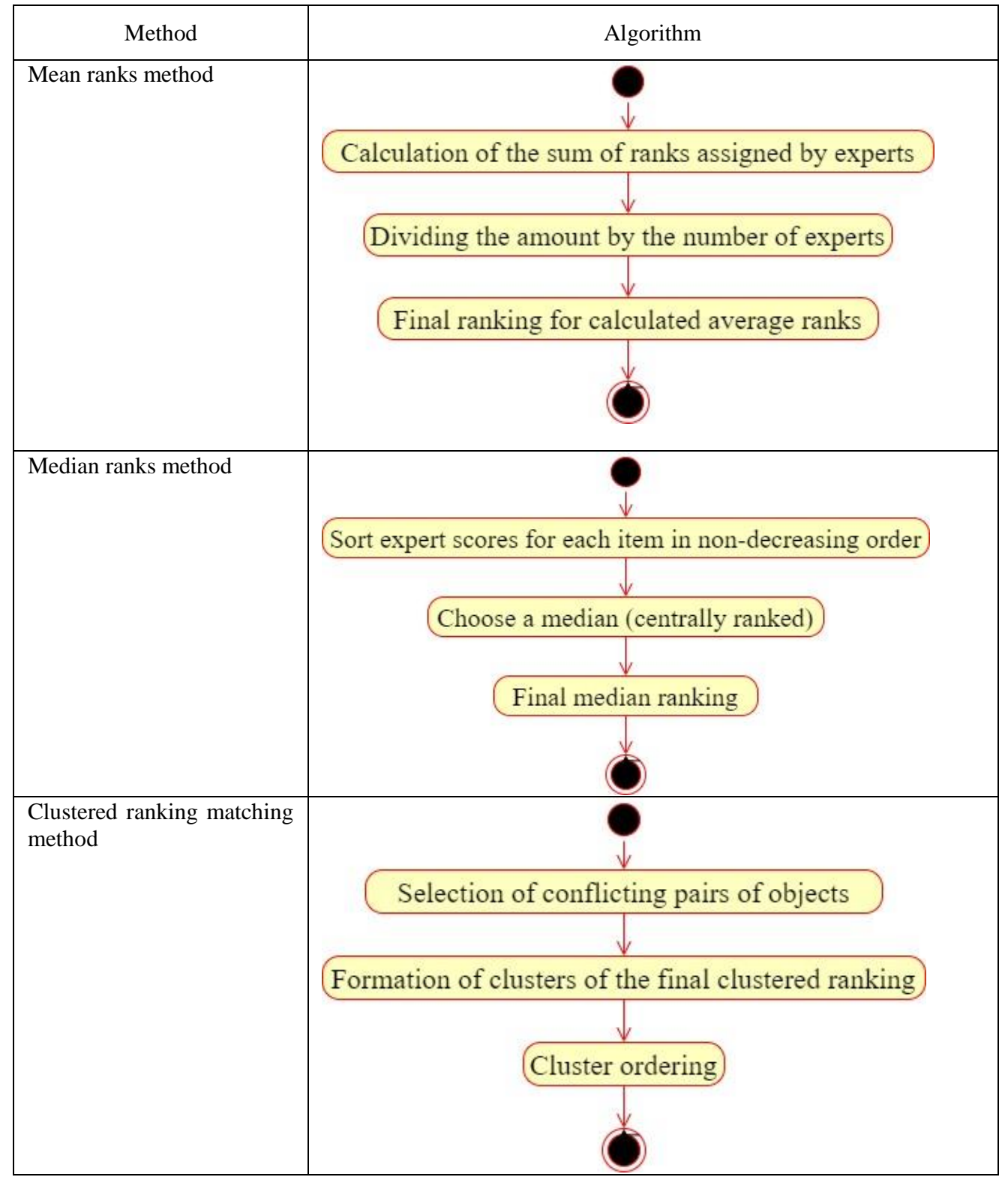

Applying the methods from Table 3, we have assessed the dynamics of the memristor market development by analyzing expert panels, as well as summarizing the data from statistical reports (MMR, 2019; MW, 2020; Kastalskiy, 2017; Berd, 2014; Pechatnick, 2010). Quantitatively the market is assessed according to basic indicators. The level of concentration of the industrial market is one of the key characteristics of its structure. Other characteristics of the market are taken into account along with concentration. The structure of the industry market is revealed by three basic indicators - the number of suppliers, the suppliers' market share, and the market concentration indicators (Kuzmin, Volkova \& Fomina, 2019).

The qualitative assessment of the representativeness of the sample for identifying the dynamics of the memristor market development indicators was based on the results of several studies that concentrated on exploring the 
trends in the memristor market (TMR, 2017; RM, 2018; Shukla \& Sharma, 2017; MM, 2017; MI, 2020; FMI, 2016; IA, 2020; MRO, 2015; AMR, 2016; TIP, 2020). When performing the analysis, we used the data from patent systems Federal Institute of Industrial Property (www.fips.ru), United States Patent and Trademark office (www.uspto.gov), European Patent Office (www.espacenet.com), application database of the World Intellectual Property Organization (www.wipo.org), as well as scientific publication and citation databases (Web of Science, Scopus, eLIBRARY.RU).

\section{Results}

Key factors that navigate the growth in the global memristor market size are advantages of memristors over other memories, increase in number of industrial robots, which require larger memory, increase in demand of tablets, watches, smart phones and other smart wearable devices, whose power capacity can significantly enhance due to memristors (MMR, 2019). According to Cisco Systems' estimates, by 2022 the number of wearable devices in the world can reach 1,105 billion units as compared to 593 million units in 2018 (Fig. 5).

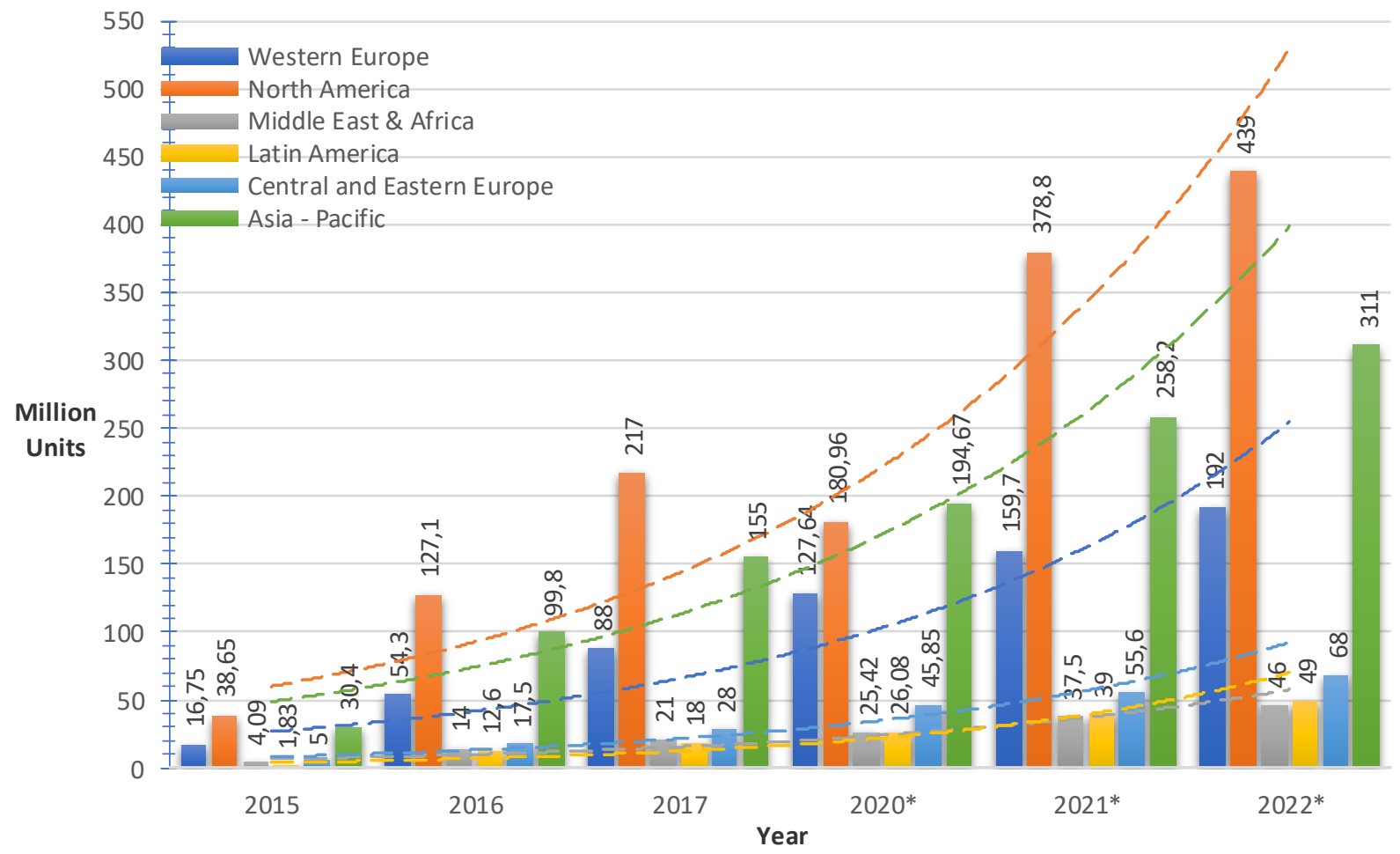

Fig. 5. The use of wearable devices with a forecast up to 2022 by region Source: (Statista, 2020).

The growing popularity of the IoT and increasing demand for neural networks open up new opportunities for participants in the memristor technology market. In 2018, the memristors market was valued at USD 278.05 million (PRN, 2019). Estimates of the market are increasing every year. Numerous forecasts indicate that the annual market growth rate will average about $80 \%$ and reach an estimate of USD 8.9 billion by 2024 and USD 13.5 billion by 2027, and there is still more to come (MI, 2020; FMI, 2016; IA, 2020).

The interest of researchers in memristors is constantly growing. Figure 6 shows the increase in the number of publications on memristors: by 2020, their number has increased 8 times. Figure 7 illustrates an increase in the 
number of memristor-related articles (according to the publication archive of Web of Science, Scopus and eLIBRARY.RU). The rise is even more significant here.

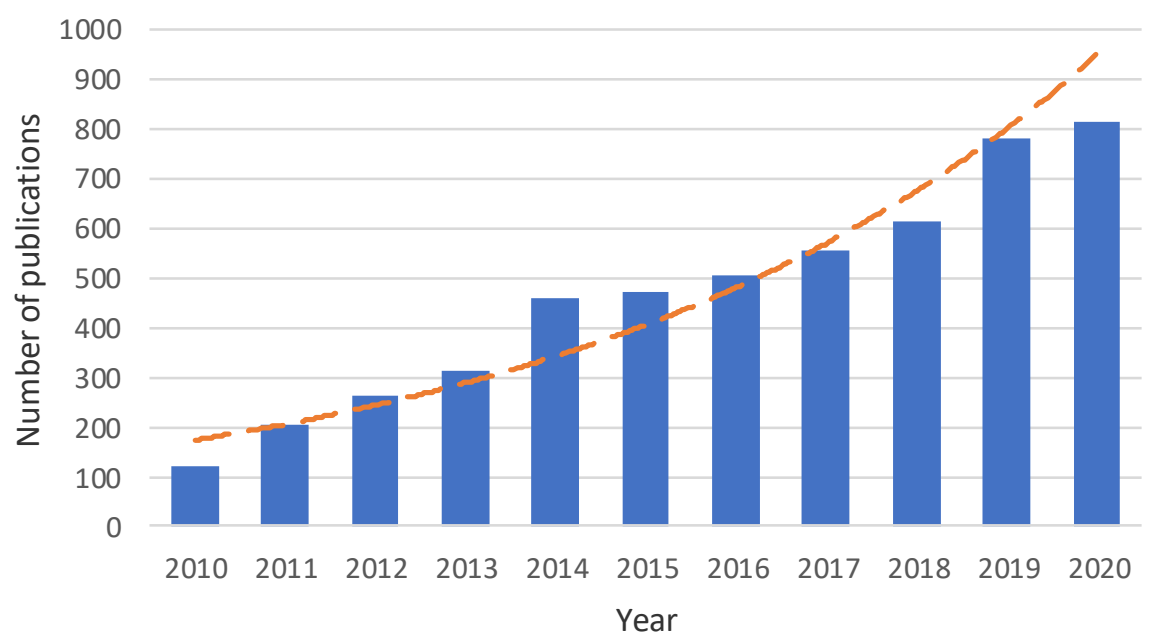

Fig. 6. The number of publications on memristor technology

Source: (Sherief et al., 2019; TMR, 2017; RM, 2018; Shukla \& Sharma, 2017).

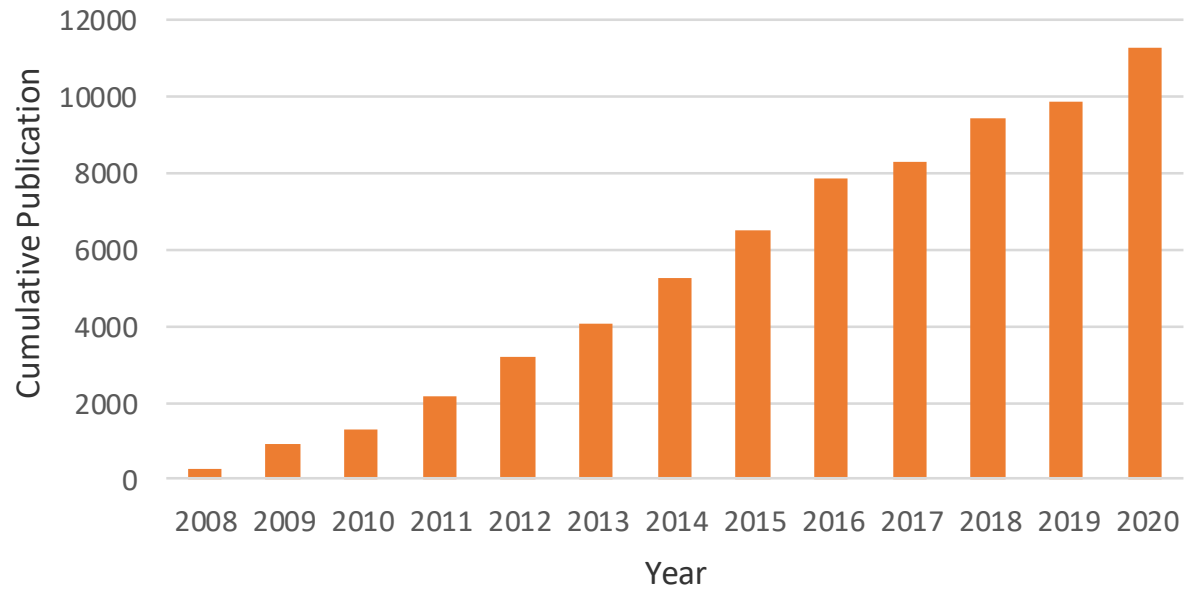

Fig. 7. Cumulative publication per year

Source: (Sherief et al., 2019; TMR, 2017; RM, 2018; Shukla \& Sharma, 2017).

The memristor market is highly competitive. Figure 8 shows that the key players and investors of the market are the following: HP development company, L.P. (www.8.hp.com); Intel Corporation (www.intel.ru); Knowm Inc (knowm.org); Micron Technology, Inc. (www.micron.com); Panasonic Corporation (www.panasonic.com); Rambus Incorporated (www.rambus.com); Samsung (www.samsung.com); San Disk Corporation (www.shop.westerndigital.com/sandisk); Sk Hynix Inc. (www.skhynix.com); and Toshiba Corporation (www.toshiba.co.jp . Most companies expand their market presence by entering various end-user segments. The effectiveness of such a strategy is grounded by forceful arguments (Toomsalu et al., 2019; Chernova et al., 2019). 


\section{ENTREPRENEURSHIP AND SUSTAINABILITY ISSUES}

ISSN 2345-0282 (online) http://jssidoi.org/jesi/ 2020 Volume 8 Number 2 (December) http://doi.org/10.9770/jesi.2020.8.2(6)

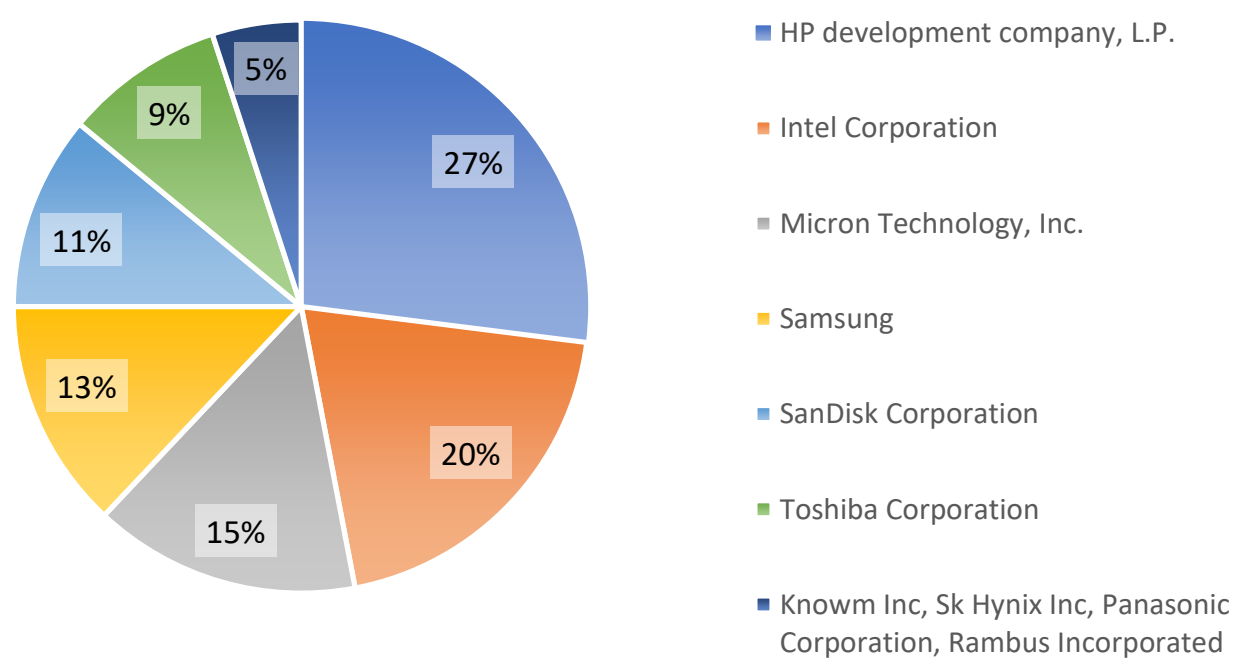

Fig. 8. Activities of global manufacturers of memristive technologies Source: (MRO, 2015).

According to Accurize Market Research (AMR, 2016), the global memristor market is geographically categorized into North America - 33\%, Europe - 27\%, Asia Pacific - 24\%, rest of the world - 16\%. North America is one of the most significant markets for memristors (Fig. 9). This is due to the high level of investment in research and development from local market players, many of which are located in the United States (Lambert, 2020). The country is also among the key participants in most memristor applications, such as neuromorphic computing, car electronics, flexible electronics, the IoT, and industrial robotics. The region's investments in edge computing and systems on a chip (SoC) are significantly higher compared to investments from companies from other regions of the world.

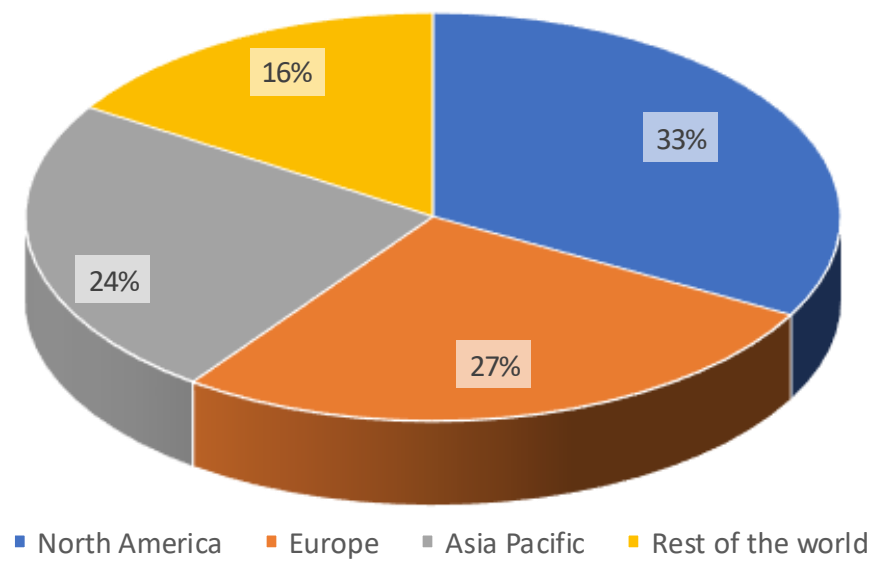

Fig. 9. The scale of the world market of memristors on a geographical basis Source: (AMR, 2016). 
When analyzing global trends in the development of memristive technology, it can be stated that they are passing through the second stage of development (Fig. 10). The first stage of this technology's development is over. Its major result is the discovery of the possibilities of creating memristors. At the moment, global memristor manufacturers are actively exploring the possibility of improving the current results to pass through the second stage and enter the third one.

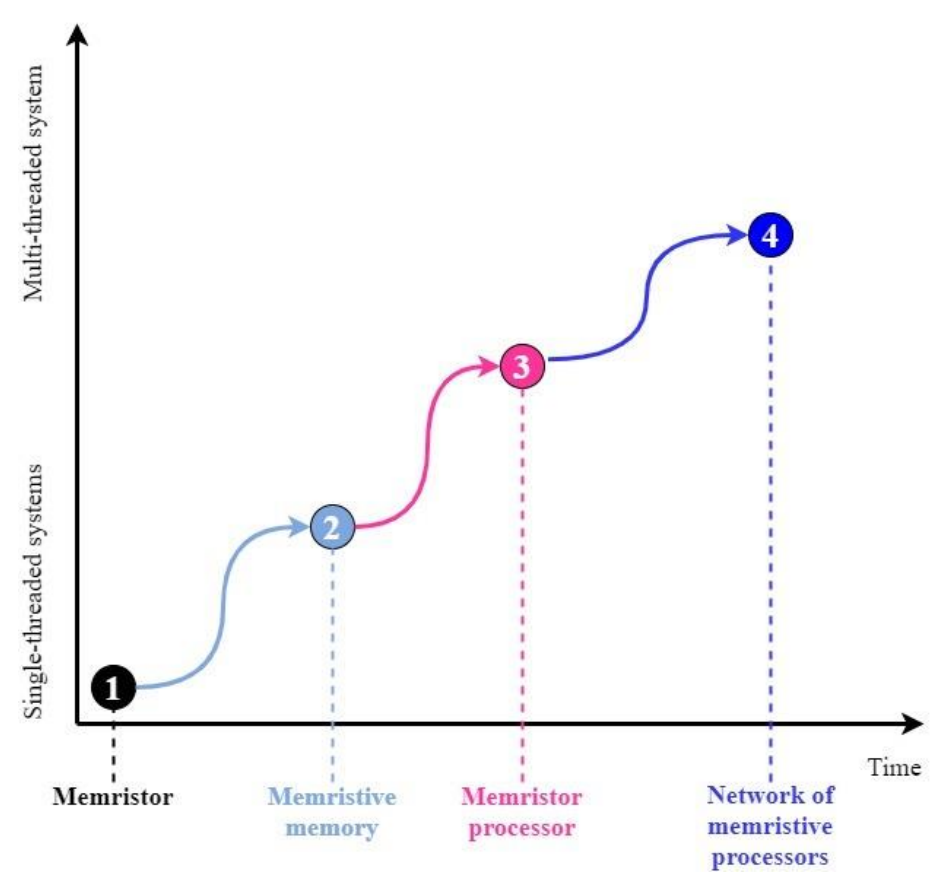

Fig. 10. The development trend of memristive technology

As with the development of processors, memristive technology will improve its capacity in the process of its further introduction and integration. In this regard, we can assert that memristors will be going through at least 4 development stages starting from single-thread systems to multi-thread ones that will take the form of a memristor processors network (Potkina \& Kholopova, 2014). With the emergence of first memristor processors capable of integrating into common computing systems, memristive technology will start being introduced and applied across all countries.

However, despite all the existing inventions, the introduction of this technology can be projected for the next decade only, since there are still a vast number of unresolved technological and economic issues, in particular, the need for substantial investment in re-equipment. Based on the analysis of the current situation using the data from patent reports and publication activity (Kastalskiy, 2017; Berd, 2014; Pechatnick, 2010; Politbook, 2020), it is possible to forecast future change in the memristive technologies market (Fig. 11). 
ENTREPRENEURSHIP AND SUSTAINABILITY ISSUES

ISSN 2345-0282 (online) http://jssidoi.org/jesi/ 2020 Volume 8 Number 2 (December) http://doi.org/10.9770/jesi.2020.8.2(6)

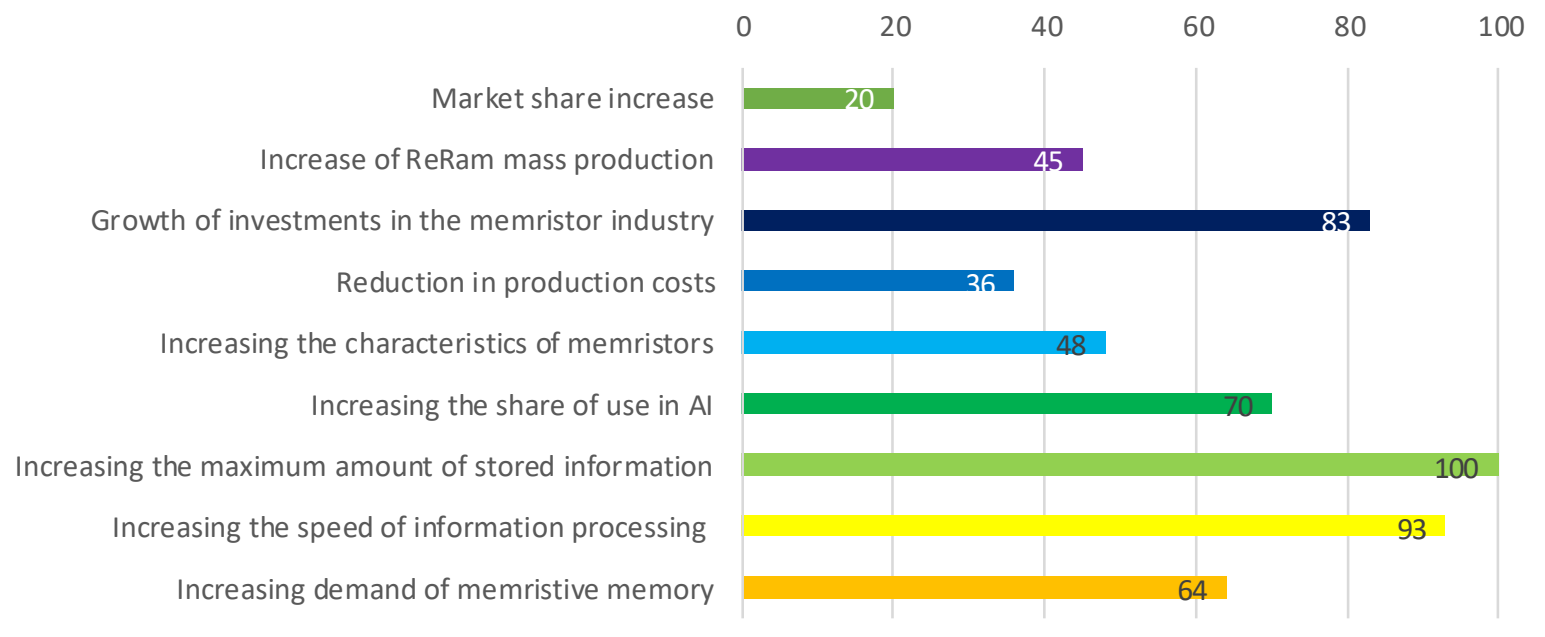

Fig. 11. Projected estimates for the implementation of memristive technologies by $2030, \%$

It can be assumed that the first breakthrough in memristive technology will happen in the field of data storage. A fundamentally new type of memory and its properties allow storing much larger amounts of data, while production costs are comparable to current high-budget solutions.

\section{Discussion}

The effect of memristive technology on the development trends in modern smart systems is presented in Fig. 12. Memristive technology is versatile. In terms of manufacturing and IT, this technology will lend powerful impetus to the development of computer technology, forecasting and automation algorithms. In the field of social technology, the introduction of memristors can significantly improve the security of personal data (Halkos \& Skouloudis, 2016; Metaxas, 2016). Implementing memristor technology in medicine will generate abundant resources for scientific research in the field of vaccines and diseases. Robotics will acquire genuine artificial intelligence that can simulate human behavior without using absolute algorithms, the variability of which is limited only by positive or negative values. 


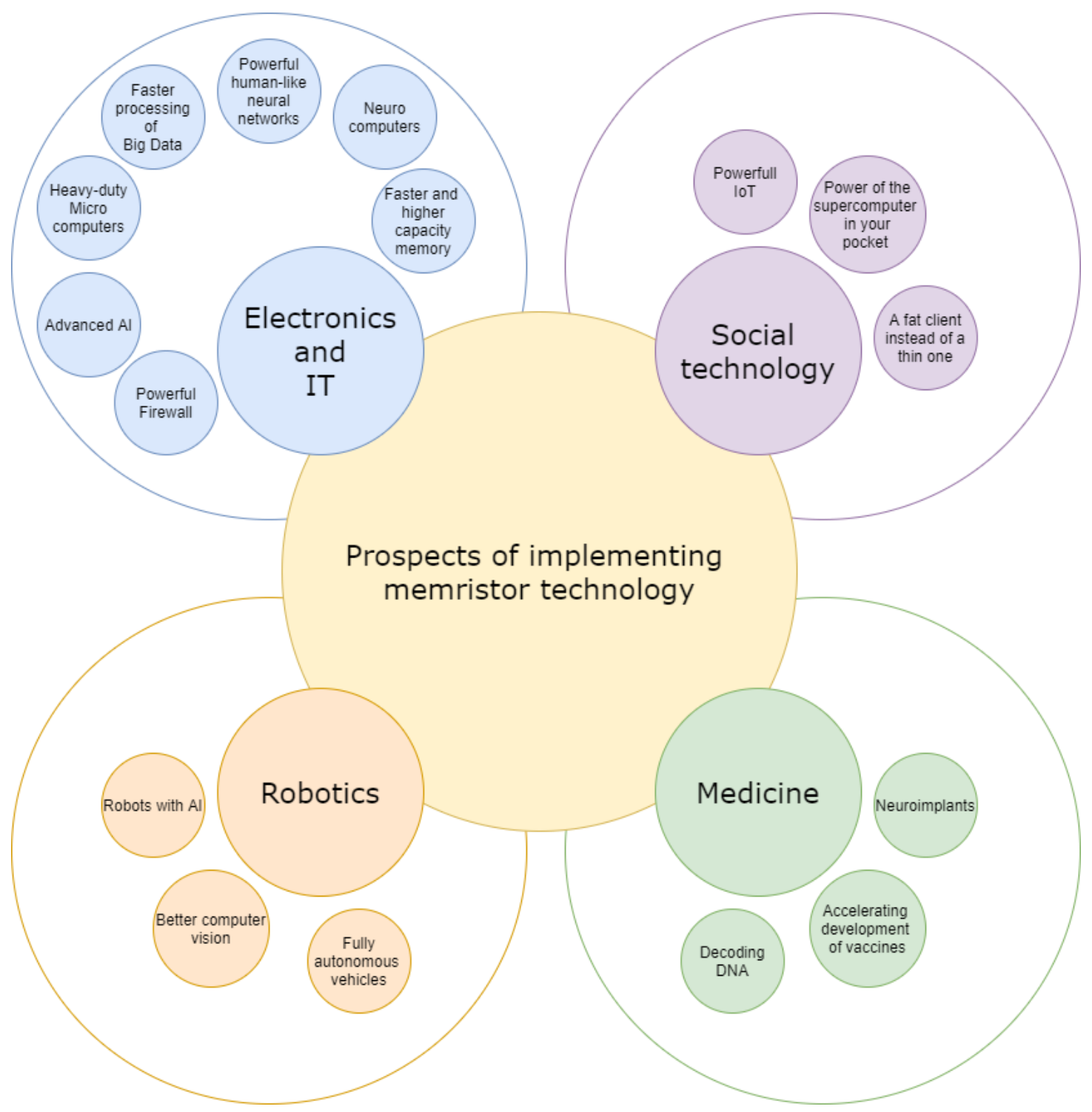

Fig. 12. Prospects of implementing memristor technology

The benefits of implementing memristive technologies, such as increased capacity and energy efficiency, will contribute to the development of Big Data. This will entail the expansion of CAD systems' capabilities while simulating the environment through creating digital twins (Vichugova, 2020).

The efficiency of the IoT is expected to rise, which will make it possible to decentralize increasingly complex mechanisms, and sensors will be able to track and transmit larger volumes of data. All devices can be synchronized within the same ecosystem and work as a single unit. Cloud storage and computing will become the crucial link between specialists in different fields, simplifying the introduction of changes and adjustments to the development and production process.

The similarity between the memristor and the synapse will make the next step forward in the field of neural networks and artificial intelligence. Neural computing productivity expanded massively will lead to even more 


\section{ENTREPRENEURSHIP AND SUSTAINABILITY ISSUES}

ISSN 2345-0282 (online) http://jssidoi.org/jesi/ 2020 Volume 8 Number 2 (December) http://doi.org/10.9770/jesi.2020.8.2(6)

efficient machine learning, and computer "vision" will move far forward, which can significantly accelerate the development of robotics. Due to memristive technologies, artificial intelligence and synaptic neural networks will be able to get closer to the power, flexibility and variability of human brain. All the aspects mentioned above are a prerequisite for further development of smart systems.

\section{Conclusions}

The present paper has concentrated on the analysis of memristive technology. Having considered the available data, one can conclude that today's market of memristor-based devices is, in the first place, a market of ideas, research studies and patents. The research interest in memristors is constantly growing. Over the last decade, the number of publications on memristors has increased 8 times. The similar dynamics is observed among studies indexed in Web of Science, Scopus and eLIBRARY.RU. The obtained estimates show that the memristor market is highly competitive and is represented by a number of active players. The majority of companies expand their market presence by entering various end-user segments. The annual market growth rate will average about $80 \%$ and near USD 8.9 billion by 2024 and USD 13.5 billion by 2027. North America is among the strongest markets for memristors. This is due to significant investment in $R \& D$ from local market players, many of which are situated in the United States. However, in terms of the memristor technology implementation, it is only possible to make forecasts for the next 10 years, since many unsolved technological and economic problems still persist.

\section{Acknowledgements}

Some results of the project were obtained with the financial support of the Ministry of Science and Higher Education for the project No. 0705-2020-0041 "Fundamental research of methods of digital transformation of the component base of microand nanosystems".

\section{References}

AMR. (2016). Memristor Market Global Scenario, Market Size, Outlook, Trend, and Forecast, 2016-2025. Accurize Market Research. Retrieved from https://www.accurizemarketresearch.com/report/memristor-market/.

Berd, K. (2014). Memristors: Is it time to rewrite textbooks? Retrieved from https://3dnews.ru/906763.

Berdyugina, O. N., Krivoshein, A. I., \& Vlasov, A. I. (2018). Technological platform for innovative social infrastructure development on basis of smart machines and principles of internet of things. Proceedings 2018 Global Smart Industry Conference (GloSIC). No. 8570062. https://doi.org//GloSIC.2018.8570062

Borodina, I., Korshunov, A., Milshina, J., Vishnevsky, K., Kiseleva, L., \& Pushkov, V. (2017). New generation electronics. Global Technology Trends, 07, 1-4.

Che, D., Safran, M., \& Peng, Z. (2013). From big data to big data mining: Challenges, issues, and opportunities. In B. Hong, X. Meng, L. Chen, W. Winiwarter, \& W. Song (Eds.), Database Systems for Advanced Applications. DASFAA 2013. Lecture Notes in Computer Science, vol. 7827. Springer, Berlin, Heidelberg. https://doi.org/10.1007/978-3-642-40270-8_1

Chernova, V. Y., Starostin, V. S., Degtereva, E. A., \& Andronova, V. I. (2019). Study of sector-specific innovation efforts: The case from Russian economy. Entrepreneurship and Sustainability Issues, 7(1), 540-552. https://doi.org/10.9770/jesi.2019.7.1(38)

Demin, A. A., \& Vlasov, A. I. (2017). Visual methods of formalization of knowledge in the conditions of the synchronous technologies of system engineering. CEE-SECR '17: Proceedings of the 13th Central \& Eastern European Software Engineering Conference in Russia. Article No.: 4. Pp. 1-7. https://doi.org/10.1145/3166094.3166098 


\section{ENTREPRENEURSHIP AND SUSTAINABILITY ISSUES}

ISSN 2345-0282 (online) http://jssidoi.org/jesi/ 2020 Volume 8 Number 2 (December) http://doi.org/10.9770/jesi.2020.8.2(6)

Emelyanov, A. V., Demin, V. A., Antropov, I. M., Tselikov, G., Lavrukhina, Z. V., \& Kashkarov, P. (2015). Effect of the thickness of the TiOx/TiO2 layers on their memristor properties. Technical Physics, 60(1), 112-115. https://doi.org/10.9770/jesi.2019.7.1(38)

FMI. (2016). Memristor Market: Global Industry Analysis and Opportunity Assessment 2016-2026. Future Market Insights. Retrieved from https://www.futuremarketinsights.com/reports/memristor-market.

Grigoriev, P. V., Krivoshein, A. I., Shakhnov, V. A., Filin, S. S., Migalin, V. S., Vlasov, A. I. (2018). Smart management of technologies: Predictive maintenance of industrial equipment using wireless sensor networks. Entrepreneurship and Sustainability Issues, 6(2), 489-502. https://doi.org/10.9770/jesi.2018.6.2(2)

Halkos, G., \& Skouloudis, A. (2016). Cultural dimensions and corporate social responsibility: A cross-country analysis. MPRA Paper 69222, University Library of Munich, Germany.

Ho, Y., Huang, G. M., \& Li, P. (2009). Nonvolatile memristor memory: Device characteristics and design implications. Proceedings of the IEEE/ACM International Conference on Computer-Aided Design. San Jose, California. Pp. 485-490. https://doi.org/10.1145/1687399.1687491

IA. (2020). Memristor Market - $\quad$ Forecast (2020-2025). IndustryARC. Retrieved from https://www.industryarc.com/Report/15092/memristor-market.html.

Jeong, H., \& Shi, L. (2019). Memristor devices for neural networks. Journal of Physics D: Applied Physics, 52(2), 023003. https://doi.org/10.1088/1361-6463/aae223

Jung, G. Y. (2004). Fabrication of a 34x34 crossbar structure at $50 \mathrm{~nm}$ half-pitch by UV-based nanoimprint lithography. Nano Lett, 4 , 1225-1229. https://doi.org/10.1021/n1049487q

Kastalskiy, I. A. (2017). Analysis of signals of network activity of biological systems and applied aspects of their use in neural interface devices. Nizhny Novgorod.

Kuzmin, E. A., Volkova, E. E., \& Fomina, A. V. (2019). Research on the concentration of companies in the electric power market of Russia. International Journal of Energy Economics and Policy, 9(1), 130-136. https://doi.org/10.32479/ijeep.7169

Lambert, T. E. (2020). Monopoly capital and innovation: An exploratory assessment of R\&D effectiveness. International Review of Applied Economics, 34(1), 36-49. https://doi.org/10.1080/02692171.2019.1620703

Lee, E. A. (2006). Cyber-physical systems - are computing foundations adequate? NSF Workshop on Cyber-Physical Systems: Research Motivation, Techniques and Roadmap. October 16-17, 2006 Austin, TX.

Lee, E. A., \& Seshia, S. A. (2011). Introduction to embedded systems - A cyber-physical systems approach. MIT Press.

Litau, E. (2018a). Information flows management as a way to overcome "Puberty challenges" of a small enterprise. ACM International Conference Proceeding Series, 34-38. https://doi.org/10.1145/3278252.3278259

Litau, E. (2018b). The information problem on the way to becoming a "Gazelle." In Proceedings of the European Conference on Innovation and Entrepreneurship, ECIE (Vol. 2018-September, pp. 394-401).

Marani, R., Gelao, G., \& Perri, A. G. (2015). A review on memristor applications. Retrieved from https://arxiv.org/ftp/arxiv/papers/1506/1506.06899.pdf.

Matkarimov, J. (2018). The use of cloud computing technology in the learning of computer science. Educational Process, 2 , 17-21.

Metaxas, T. (2016). Corporate social responsibility in European organizations: A universal idea? Journal of Eurasian Social Dialogue, $1(2), 30-40$.

MI. (2020). Global memristors market - growth, trends, and forecast (2020-2025). Mordor Intelligence. Retrieved from https://www.mordorintelligence.com/industry-reports/memristor-market.

MM. (2017). Next-Generation Memory Market by Technology (Volatile (HMC and HBM), and Nonvolatile (MRAM, FRAM, RERAM, 3D XPoint, NRAM)), Wafer Size (200 mm, $300 \mathrm{~mm}$, and $450 \mathrm{~mm}$ ), Application, and Geography - Global Forecast to 2023. Markets and Markets. Retrieved from https://www.marketsandmarkets.com/Market-Reports/Memristor-Memory-Market-632.html. 


\section{ENTREPRENEURSHIP AND SUSTAINABILITY ISSUES}

ISSN 2345-0282 (online) http://jssidoi.org/jesi/ 2020 Volume 8 Number 2 (December) http://doi.org/10.9770/jesi.2020.8.2(6)

MMR. (2019). Global Memristor Market - Industry Analysis and Forecast (2019-2026) - by Type, Industry Vertical, and by Geography. Maximize Market Research. Retrieved from https://www.maximizemarketresearch.com/market-report/global-memristor$\underline{\text { market/29514/\#details. }}$

MRO. (2015). Memristor Market (By Type: Spin Based \& Magnetic Memristor, and Molecular \& Ionic Film Memristor; By Industry Vertical; By Geography) Global Scenario, Market Size, Outlook, Trend and Forecast, 2015-2024. Market Research Outlet. Retrieved from https://www.marketresearchoutlet.com/report/memristor-market.

Muraviev, K. A., Prudius, A. A., Vlasov, A. I., \& Uzenkov, D. A. (2019). Load balancing in big data processing systems. International Review of Automatic Control, 12(1), 42-47. https://doi.org/10.15866/ireaco.v12i1.16808

MW. (2020). Global Memristors Market In-depth Analysis, Competitive Landscape and Future Scope from 2020 to 2025. Market Watch. Retrieved from https://www.marketwatch.com/press-release/global-memristors-market-in-depth-analysis-competitive-landscape-andfuture-scope-from-2020-to-2025-2020-05-12?mod=mw_quote_news.

Pechatnick. (2010). How will memristors change the IT market? Why won't a photon computer appear? Why did HP acquire sophisticated science equipment on eBay? Pechatnick. Retrieved from https://pechatnick.com/news/kak-memristori-izmenyat-it-rinok-pochemy-fotonniikomputer-ne-poyavitsya-pochemy-hp-priobretala-slojnoe-naychnoe-oborydovanie-na-ebay.

Politbook. (2020). The concept of a memristiveneurohybrid chip for use in neurointerfaces and neuro prostheses was developed by scientists from Lobachevsky University in collaboration with colleagues from Russia, Italy, China and the USA. Retrieved from https://politbook.ru/articles/novosti/kontseptsiya-memristivnogo-neyrogibridnogo-chipa-dlya-ispolzovaniya-v-neyrointerfeysakh-ineyroprote.

Potkina, E. S., \& Kholopova, L. A. (2014). Development of information technologies. Concept, 4, ART 14612, 1-4.

PRN. (2019). Global Memristors Market - Growth, Trends, and Forecast (2019-2024). PR Newswire. Retrieved from https://www.prnewswire.com/news-releases/the-memristors-market-was-valued-at-usd-278-05-million-in-2018-and-is-expected-reach-usd8879-25-million-by-2024-to-register-a-cagr-of-52-7-during-the-forecast-period-2019--300933803.html.

Puurunen, R. L. (2005). Surface chemistry of atomic layer deposition: A case study for the trimethylaluminum/water process. Journal of Applied Physics, 97, 121301. https://doi.org/10.1063/1.1940727

RM. (2018). Memristor Market - Forecasts from 2018 to 2023. Research and Markets. Retrieved from https://www.researchandmarkets.com/reports/4618275/memristor-market-forecasts-from-2018-to-2023.

Sampath, M., Mane, P. S., \& Ramesha, C. K. (2015). Hybrid CMOS-memristor based FPGA architecture. 2015 International Conference on VLSI Systems, Architecture, Technology and Applications (VLSI-SATA). Bangalore. Pp. 1-6. https://doi.org/10.1109/VLSI$\underline{\text { SATA.2015.7050461 }}$

Sherief, N., Ahmed, S. D., El-Sayed, M. E., \& Hassan, M. (2019). Memristor NRSC 2019. National Radio Science Conference (NRSC 2019).

Shukla, G., \& Sharma, K. (2017). Memristor Market by Type (Molecular \& Ionic Film memristor and Spin Based \& Magnetic Memristor) and Industry Vertical (Electronics, IT \& Telecom, Industrial, Aerospace \& Defense, Automotive and Healthcare) - Global Opportunity Analysis and Industry Forecast, 2014-2022. Report Overview. Retrieved from https://www.alliedmarketresearch.com/memristor-market.

Snider, G., Amerson, R., Carter, D., Abdalla, H., Qureshi, M. S., Leveile, J., Versace, M., ... Mingolla, E. (2011). From synapses to circuitry: Using memristive memory to explore the electronic brain. Computer, 44(2), 21-28. https://doi.org/10.1109/MC.2011.48

Statista. (2020). Number of connected wearable devices worldwide by region from 2015 to 2022 . Retrieved from https://www.statista.com/statistics/490231/wearable-devices-worldwide-by-region/

$\begin{array}{lllll}\text { The fourth } & \text { revolution. } & \text { (2017). } & \text { Retrieved }\end{array}$ www.tadviser.ru/index.php/Статья:Четвертая_промышленная_революция_(Industry_Индустрия_4.0).

TIP. (2020). Memristor Market Forecast to 2027. The Insight Partners. Retrieved from https://www.theinsightpartners.com/reports/memristor-market/. 


\section{ENTREPRENEURSHIP AND SUSTAINABILITY ISSUES}

ISSN 2345-0282 (online) http://jssidoi.org/jesi/ 2020 Volume 8 Number 2 (December) http://doi.org/10.9770/jesi.2020.8.2(6)

TMR. (2017). Memristor Market - Global Industry Analysis, Size, Share, Growth, Trends and Forecast 2017-2025. Transparency Market Research. Retrieved from https://www.transparencymarketresearch.com/memristor-market.html.

Toomsalu, L., Tolmacheva, S., Vlasov, A., \& Chernova, V. (2019). Determinants of innovations in small and medium enterprises: A European and international experience. Terra Economicus, 17(2), 112-123. https://doi.org/10.23683/2073-6606-2019-17-2-112-123

Vasilyev, V. A., \& Chernov, P. S. (2012). Memristor as a promising component of nanoelectronics. Proceedings of the International scientific and technical conference INTERMATIC - 2012. Part 4. Pp. 91-94.

Vera-Tasama, A., Gomez-Cano, M., \& Marin-Hurtado, J. I. (2019). Memristors: A perspective and impact on the electronics industry. 2019 Latin American Electron Devices Conference (LAEDC), Armenia, Colombia, pp. 1-4. https://doi.org/10.1109/LAED.2019.8714735

Veretennikov, A. V. (2017). BigData: Big data analysis today. Young Scientist, 32(166), 9-12.

Vichugova, A. (2020). Digitalization of production and digital twins: combining PLM, IoT and Big Data. Retrieved from https://www.bigdataschool.ru/bigdata/digital-twin-plm-iot-big-data.html.

Wasa, K., \& Hayakawa, S. (1993). Handbook of sputter deposition technology. William Andrew.

Whitaker, D. A., Egan, D., O’Brien, E., \& Kinnear, D. (2018). Application of multivariate data analysis to machine power measurements as a means of tool life predictive maintenance for reducing product waste. Retrieved from https://arxiv.org/abs/1802.08338.

Witten, I. H., \& Frank, E. (2016). Data mining: Practical machine learning tools and techniques. Morgan Kaufmann. Pp. 7-9.

Yener, S. C., \& Kuntman, H. (2012). A new CMOS-based memristor implementation. In Proc. of 2012 International Conference on Applied Electronics. Pilsen (Czech Republic). Pp. 345-348.

Yudin, A., Kolesnikov, M., Salmina, M., \& Vlasov, A. (2017). Project oriented approach in educational robotics: From robotic competition to practical appliance. Advances in Intelligent Systems and Computing, 457, 83-94. https://doi.org/10.1007/978-3-319-42975-5_8

Andrey I. VLASOV, Cand.Sci. (Engineering), Associate professor of the department IU4 "Designing and Technology of Electronic Equipment", assistant manager as IU4 chair on scientific work of the Bauman Moscow State Technical University (Moscow, Russian Federation). Research interests: neural networks, stable operating systems, Internet of things (IoT), public-private partnerships, economic sustainability.

ORCID ID: orcid.org/0000-0001-5581-4982

Ivan V. GUDOSHNIKOV, Master student of the department IU4 "Designing and Technology of Electronic Equipment" of the Bauman Moscow State Technical University (Moscow, Russian Federation). Research interests: systems analysis, systems technology, Internet of things (IoT).

ORCID ID: orcid.org/0000-0003-0548-4860

Vladimir P. ZHALNIN, Cand.Sci. (Engineering), Associate professor of the department IU4 "Designing and Technology of Electronic Equipment", Bauman Moscow State Technical University (Moscow, Russian Federation). Mr. Zhalnin has published over 30 research works. The main area of his research includes micro- and nanoelectronics and nanotechnology. Research interests: memristive technologies, systems technology, economic sustainability.

ORCID ID: orcid.org/0000-0002-9645-2436 


\title{
ENTREPRENEURSHIP AND SUSTAINABILITY ISSUES
}

ISSN 2345-0282 (online) http://jssidoi.org/jesi/ 2020 Volume 8 Number 2 (December) http://doi.org/10.9770/jesi.2020.8.2(6)

\begin{abstract}
Aksultan T. KADYR, Masters student of the department IU4 "Designing and Technology of Electronic Equipment" of the Bauman Moscow State Technical University (Moscow, Russian Federation). Research interests: systems analysis, systems technology, Internet of things (IoT).

ORCID ID: orcid.org/0000-0003-4462-8281

Vadim A. SHAKHNOV, Corresponding member of RAS, Dr.Sci. (Engineering), Professor, Head of the department IU4 "Designing and Technology of Electronic Equipment" of the Bauman Moscow State Technical University (Moscow, Russian Federation). Research interests: multidimensional data, industrial production, technological control, modeling and optimization of processes, knowledge management, professional education.
\end{abstract}

ORCID ID: orcid.org/0000-0003-4013-1905

Make your research more visible, join the Twitter account of ENTREPRENEURSHIP AND SUSTAINABILITY ISSUES:

@Entrepr69728810

Copyright (C) 2020 by author(s) and VsI Entrepreneurship and Sustainability Center

This work is licensed under the Creative Commons Attribution International License (CC BY).

http://creativecommons.org/licenses/by/4.0/

c) (i) Open Access 